other East and Central Africa. The groups will be free to settle the range and method of theit inquiries and will spend about six months in the field consulting with educationists, administrators, and members of the public on the policy and practice of education for Africans up to and including the secondary level. The visits of the groups will, it is hoped, be followed by a conference in the United Kingdom in I 952 to which representative educational experts from each territory will be invited.

\title{
Sudan Publications Bureau
}

The Publications Section of the new division for Adult Education of the Sudan Ministry of Education was constituted at the beginning of $195 \mathrm{I}$ and incorporates the two existing publications bureaux at Khartoum and Juba. The work done by the bureaux may be considered under three heads : the production of school text-books; the preparation of material for use in literacy campaigns; the provision of reading-matter suitable for literate schoolleavers and country people. In connexion with the last-named undertaking, one of the first ventures of the bureau at Khartoum was the production of an illustrated youth magazine which proved to be so popular that its present circulation is in the neighbourhood of 20,000 copies per issue. A special problem exists in the Southern Provinces owing to the multitude of languages, and the fact that most of those who can read or write have learnt in village schools in their own vernacular language. The needs of these readers are being met by the production of cheap booklets written or translated into one or other of the fourteen main tribal languages. To help the better educated a quarterly magazine Future was initiated, which includes stories, articles, and pictures and also publishes contributions by Sudanese writers. A four years' course of Arabic readers, as well as teachers' lessons in oral Arabic have been produced and printed by the Southern Bureau.

\section{Sudan Literacy Campaigns}

LITERACY campaigns on a wide scale have been started in the Northern, Blue Nile, and Kordofan Provinces in which students from Gordon Memorial College, Wadi Seidna Secondary School, and the teachers' Training College, Bakht ex Ruda, are taking an active part. A small campaign for work among women is being conducted under the direction of the Gezira Welfare Officer with assistance from girls from Gordon Memorial College, Wad Medani Girls' Intermediate School, and the Gezira Girl Guides.

\section{Local Government in Eastern Nigeria}

IN eastern Nigeria, in the absence of strong traditional rulers, an attempt is being made to develop a system of local government based, as in Kenya and parts of Uganda, on representative area and district councils. The first Nigerian County Council-the Ikot Ekpene County Council-has now been constituted. It is composed of 40 elected councillors, 36 of whom are elected by the villages in the areas covered by the three newly created rural district councils, the remaining four being elected from the urban district council which administers the affairs of Ikot Ekpene town. The secretary and treasurer of the County Council are Africans who have taken a local government training course in the United Kingdom. In addition to the County Council there are three rural district councils, one urban district council, and 23 local councils. The backbone of the system is the local council, members of which are elected by areas comprising is to 20 villages. Each local council elects its representatives to the county council and the rural district councils. The spheres of responsibility of each type of council have been defined; the county council has wide powers over public health, highways, and education; the rural district councils are 